\title{
Prevalence and Risk Factors for Hepatitis Delta Virus Transmission among HBsAg Positive Blood Donors in Brazzaville, Congo
}

\author{
Serge 0. Mokono ${ }^{1,2}$, Chaldam J. Mbani ${ }^{1,3}$, Brunel M. Angounda ${ }^{1,3}$, Boris S. Bakoua ${ }^{1}$, \\ Sara R. Mbao-Bongo', Edwige P. Louanga Nanitelamio' ${ }^{1,2}$, Fabien R. Niama ${ }^{3}$, \\ Donatien Moukassa ${ }^{1,2}$ \\ ${ }^{1}$ National Center of Blood Transfusion, Brazzaville, Congo \\ ${ }^{2}$ Faculty of Health Sciences, Marien NGOUABI University, Brazzaville, Congo \\ ${ }^{3}$ Faculty of Science and Technology, Marien NGOUABI University, Brazzaville, Congo \\ Email: oscarmokono@yahoo.fr
}

How to cite this paper: Mokono, S.O., Mbani, C.J., Angounda, B.M., Bakoua, B.S., Mbao-Bongo, S.R., Nanitelamio, E.P.L., Niama, F.R. and Moukassa, D. (2021) Prevalence and Risk Factors for Hepatitis Delta Virus Transmission among HBsAg Positive Blood Donors in Brazzaville, Congo. Journal of Biosciences and Medicines, 9, 43-50. https://doi.org/10.4236/jbm.2021.98004

Received: June 11, 2021

Accepted: August 7, 2021

Published: August 10, 2021

Copyright $\odot 2021$ by author(s) and Scientific Research Publishing Inc. This work is licensed under the Creative Commons Attribution International License (CC BY 4.0).

http://creativecommons.org/licenses/by/4.0/ (c) (i) Open Access

\begin{abstract}
Background: Hepatitis D virus (HDV) is a defective virus that requires the presence of hepatitis B virus (HBV) for replication. It is a major cause of severe acute and chronic hepatitis $\mathrm{B}$. The objective of this study was to determine the prevalence and risk factors of HDV in blood donors. Methods: This was a descriptive, cross-sectional study involving HBsAg-positive blood donors covering the period from July to December 2020. Testing for HDV RNA was performed by conventional two-step RT-PCR. Data were analysed using SPSS version 22 software. Result: Of $113 \mathrm{HBsAg}$ positive samples included in the study 22 or $19.5 \%$ were HDV positive. The prevalence of HDV was higher in the age group $31-45$ years (45.5\%), in male donors (71.4\%) and in donors with secondary education (50.0\%). Furthermore, 55.4\% belonged to the family donor category. A significant statistical difference was observed between HDV infection, tattoos, piercings and multiple sexual partners. Conclusion: This study shows a high prevalence of HDV among blood donors in Brazzaville.
\end{abstract}

\section{Keywords}

Prevalence, HDV, Blood Donors, Brazzaville, Risk Factors

\section{Introduction}

Hepatitis, an inflammation of the liver, can be caused by various viruses such as hepatitis A, B, C, D and E. Some of these are transmitted through food, while 
others are transmitted exclusively through blood and contaminated blood products [1]. Hepatitis D virus (HDV) is a small, defective RNA virus that requires hepatitis B virus (HBV) to complete its replication cycle within host cells [2], and infects only HBV surface antigen (HBsAg) positive individuals [3]. HDV infection is therefore the result of HBV and HDV co-infection or HDV superinfection of chronically HBV infected patients. In combination with HBV, HDV causes much more severe disease than HBV alone [4]. HDV is currently well known to cause a range of acute and chronic liver diseases [5]. Individuals with HBV-HDV co-infection may have more severe acute disease and be at greater risk of fulminant hepatitis, cirrhosis and hepatocellular carcinoma (HCC) than those with HBV infection alone [6] [7]. As with HBV, transmission of HDV occurs through sexual intercourse, blood or horizontal transmission [8]. It is estimated that 62 to 72 million people worldwide may be living with HDV [9]. HDV infection has a worldwide distribution, but its frequency varies greatly throughout different geographic regions. It is highly endemic in the Middle East, in the Mediterranean area, in the Amazonian region, and in several African countries [10]. In Africa, a quarter of the estimated 65 million chronic HBV carriers are suspected of being HDV carriers [11]. In the Republic of Congo, the prevalence of HDV is $12.2 \%$ in the general population [12]. Despite this prevalence, no study on the prevalence of HDV has been conducted among blood donors in Brazzaville. It is in this context that we conducted this study to determine the prevalence and risk factors of HDV transmission among blood donors in Brazzaville.

\section{Methods}

\subsection{Study Design and Population}

This was a cross-sectional study of HBsAg positive blood donors conducted at the National Blood Transfusion Centre for sample collection and at the National Public Health Laboratory for molecular analysis covering the period from June to December 2020.

Sampling was done by the simple random method among HBsAg positive blood donors. Thus, our sample size was determined according to the Schwartz formula: $\mathrm{n}=(\mathrm{z})^{2} \mathrm{p}(1-\mathrm{p}) / \mathrm{d}^{2}$ with $\mathrm{n}=$ sample size, $\mathrm{z}=95 \%$ confidence level, $\mathrm{z}=$ 1.96, $\mathrm{p}=\mathrm{HDV}$ prevalence in Brazzaville (11.12\%) taking into account the study on Seroprevalence and Molecular Biodiversity of Hepatitis B and Delta Virus Infections in the Republic of Congo [12], $\mathrm{d}=0.05$ margin of error allowed. For based on this, the minimum number of subjects with HBsAg to be included in this study was 113 .

A survey form was used to collect socio-demographic information (Sex, Age, Profession, type of donation) and risk factors. Informed consent was obtained from each donor in this study. Ethical approval for this survey was obtained from the Health Sciences Research Ethics Committee. Blood donors who did not give informed consent were not included in the study. 
The inclusion criteria were: all HBsAg-positive blood donors aged 18 - 60 years were included in the study, having agreed to participate in the study after informed consent and signing a voluntary commitment form.

\subsection{Sample Collection}

Plasma samples from 113 blood donors tested positive for HBsAg by ELISA (Monolisa $^{\mathrm{Tm}}$ HBsAg Ultra, Bio-Rad, Marne-La-Coquette, France) were aliquoted into cryotubes and stored at $-40^{\circ} \mathrm{C}$.

\subsection{Biological Screening}

The presence of HDV RNA was detected in HBsAg-positive plasma samples by conventional two-step RT-PCR. Nucleic acids were extracted from $200 \mu \mathrm{l}$ of plasma with the system invitrogen superscript III RT platinum kit (Invitrogen) according to the manufacturer's recommendations. Amplification was performed using the primer pairs

D2(5'-ACAAGGAGAGGCAGGATCACCGAC3')/D3(5'GAGATGCCATGCCG ACCCGAAGAG-3') and

D1(5'-GCCCAGGTCGGACCGCGAGGAGGT-3')/D4(5'GAAGGAAGGCCCT

CGAGAACAAGA-3') used by Mongo-Onkouo et al. [12] in a TECHNE TC-312 thermal cycler. The amplified PCR products were subjected to electrophoresis on a $2 \%$ agarose gel.

\subsection{Statistical Analysis}

Statistical analysis of the data was carried out using SPSS version 22 software. The $\mathrm{Chi}^{2}$ test and Fisher's exact test were used to compare proportions in order to establish the different associations between the parameters studied. Differences were considered significant at a $\mathrm{p}$-value $<0.05$.

\section{Results}

\subsection{General Characteristics of the Blood Donors}

A total of $113 \mathrm{HBsAg}$ positive blood donors were included in this study of which 27 were female $(23.89 \%)$ and 86 were male $(76.10 \%)$. The mean age of the study population was $33.57 \pm 10.54$ with the extremes ranging from 18 to 60 years. The age group of 31 - 45 years (55.75\%) was the most represented. The majority of the study participants were family donors (65.48\%), 44.24\% had secondary education and $62.83 \%$ were single.

\subsection{Prevalence and Risk Factors for HDV Infection}

HDV RNA was detected in $19.5 \%$ of the samples. The prevalence of HDV was higher in the 31 - 45 age group (45.5\%), in male donors $(71.4 \%)$ and in donors with secondary education (50.0\%). Furthermore, 54.5\% of the blood donors included in the study belonged to the category of family donors, while regular donors accounted for only $18.2 \%$ of HDV infections in this study. Regarding ma- 
rital status, the prevalence of HDV was higher among single donors (59.09\%) (Table 1).

The risk factors associated with infection are presented in Table 2. Tattoos

Table 1. Prevalence of HDV by socio-demographic characteristics.

\begin{tabular}{|c|c|c|c|c|}
\hline Characteristics & $\begin{array}{c}\text { Total } \\
\mathrm{N}=113\end{array}$ & $\begin{array}{c}\text { VHD+ } \\
(\mathrm{n}=22)(\%)\end{array}$ & OR (95\% IC) & P-value \\
\hline \multicolumn{5}{|l|}{ Sexe } \\
\hline Male & 86 & $21(71.4)$ & $8.40(1.07-65.71)$ & \multirow{2}{*}{0.040} \\
\hline Female & 27 & $1(28.6)$ & 1 & \\
\hline \multicolumn{5}{|l|}{ Age } \\
\hline $18-30$ & 35 & $9(40.9)$ & $1.38(0.31-6.05)$ & 0.665 \\
\hline $31-45$ & 63 & $10(45.5)$ & $0.75(0.17-3.16)$ & 0.533 \\
\hline $46-60$ & 15 & $3(13.6)$ & 1 & \\
\hline \multicolumn{5}{|l|}{ Category of Donors } \\
\hline Family Replacement & 74 & $12(54.5)$ & $0.53(0.14-1.95)$ & 0.342 \\
\hline Regular & 15 & $4(18.2)$ & 1 & \\
\hline Voluntary & 24 & $6(27.3)$ & $0.91(0.21-3.91)$ & 0.907 \\
\hline \multicolumn{5}{|l|}{ Education } \\
\hline No school & 10 & $1(4.54)$ & 1 & \\
\hline Primary & 8 & $2(9.09)$ & $2.40(0.18-30.52)$ & 0.499 \\
\hline Secondary & 50 & $11(50.0)$ & $2.86(0.33-24.47)$ & 0.335 \\
\hline University & 45 & $8(36.37)$ & $2.59(0.29-22.91)$ & 0.391 \\
\hline \multicolumn{5}{|l|}{ Marital status } \\
\hline Single & 71 & $13(59.09)$ & $1.56(0.46-5.28)$ & 0.115 \\
\hline Married & 32 & $4(18.18)$ & 1 & \\
\hline Cohabiting & 18 & $5(22.72)$ & $2.23(051-9.69)$ & 0.283 \\
\hline
\end{tabular}

OR: odds ratio; CI: confidence Interval; 1: referent.

Table 2. Prevalence according to risk factors for transmission.

\begin{tabular}{|c|c|c|c|c|}
\hline Risks factors & $\begin{array}{c}\text { Total } \\
\mathrm{N}=113\end{array}$ & $\begin{array}{c}\text { HDV } \\
(n=22)(\%)\end{array}$ & OR (95\% IC) & P-value \\
\hline \multicolumn{5}{|l|}{ Scarification } \\
\hline Yes & 40 & $4(18.18)$ & $0.33(0.10-1.08)$ & \multirow{2}{*}{0.412} \\
\hline No & 73 & $18(81.82)$ & 1 & \\
\hline \multicolumn{5}{|l|}{ Surgical operation } \\
\hline Yes & 29 & $5(27.73)$ & $0.82(0.27-2.46)$ & \multirow{2}{*}{0.72} \\
\hline No & 84 & $17(72.27)$ & 1 & \\
\hline \multicolumn{5}{|l|}{ Tattooing } \\
\hline Yes & 33 & $12(54.54)$ & $4.01(1.51-10.55)$ & \multirow{2}{*}{0.007} \\
\hline No & 80 & $10(45.46)$ & 1 & \\
\hline \multicolumn{5}{|l|}{ Drug use } \\
\hline Yes & 28 & $2(9.09)$ & $0.25(0.05-1.14)$ & \multirow{2}{*}{0.095} \\
\hline No & 85 & $20(90.91)$ & 1 & \\
\hline \multicolumn{5}{|l|}{ Ear piercing } \\
\hline Yes & 29 & $11(50)$ & $4.05(1.51-10.82)$ & \multirow{2}{*}{0.005} \\
\hline No & 84 & $11(50)$ & 1 & \\
\hline \multicolumn{5}{|c|}{ Multiple sexual exposure } \\
\hline Yes & 41 & $13(59.1)$ & $3.25(1.24-8.48)$ & \multirow{2}{*}{0.013} \\
\hline No & 72 & $9(40.9)$ & 1 & \\
\hline
\end{tabular}


$(\mathrm{OR}=4.01 ; 95 \% \mathrm{CI}: 1.51-10.55)$, piercings $(\mathrm{OR}=4.05 ; 95 \% \mathrm{CI}: 1.51-10.82)$ and multiple sexual partners $(\mathrm{OR}=3.25$; 95\% CI: $1.24-8.48)$ were the predominant risk factors among HDV positive blood donors. A statistically significant difference was observed between HDV infection, tattoos, piercings and multiple sexual partners.

\section{Discussion}

Viral hepatitis delta remains one of the major public health problems in the world. It is estimated that 62 to 72 million people are living with HDV worldwide [9]. In the Republic of Congo, very few studies have been published on HDV. The overall objective of this study was to determine the prevalence and risk factors of HDV among blood donors in Brazzaville. The absence of serological markers for HDV (antibodies and antigens) and the small sample size were a limitation in the qualitative interpretation of the results. The present study shows a high prevalence of HDV (19.5\%) confirming the results of Mongo-Onkouo et al. (2018) [12] which indicate that Congo is a country with high endemicity. This prevalence is lower than the rates reported by several authors in Mauritania and Romania, which are respectively $20.1 \%$ and $23.1 \%$ [13] [14]. However, our result is still higher than those found by Delfino et al. (2013) in Argentina [15], Uzun et al. (2014) in Iran [16], Sawadogo et al. (2016) in Burkina-Faso [17], Luma et al. (2017) in Cameroon [18] and Gomaa et al. (2013) in Egypt [19]. This difference is attributable to the difference in the size of the study populations, genetic and socioeconomic factors, and the techniques used for HDV detection. In agreement with previous studies [13] [16] [17], a significantly high prevalence was found in male blood donors. This result could be explained by the fact that the blood donor population is predominantly male. Indeed, obstetric factors, including pregnancy and breastfeeding, limit many women to donating blood. The prevalence of HDV was high in the family donor population. This finding is consistent with several studies indicating that this type of donor is at high risk of transmitting blood-borne infections [20] [21]. Indeed, this type of blood donor, in the interest of saving their sick relative, is more likely to conceal risk behaviours for transmission of infectious agents by transfusion as well as the fear of not being admitted to a blood donation. The mean age of the infected population was $30.50 \pm 2.12$. This result is similar to that of Mumtaz et al. (2005) [10] in Pakistan who reported a mean age of $32.7 \pm 14.7$ and Alizadeh et al. [22] in Iran who observed a mean age of $36.9 \pm 12.6$. This predominance of younger age could be explained by the fact that HBV infection, which is associated with $\mathrm{HDV}$, is chronic and much more common in early childhood. However, age is unlikely to be a factor influencing the results, as our study focused on the blood donor population and only individuals between the ages of 18 and 60 are allowed to donate blood. HDV RNA was mainly detected in plasma samples from single blood donors. This would indicate that intra-familial transmission is probably not an important source of HDV transmission in this population. This 
result is contrary to that reported by Mansour et al. (2012) in Mauritania who found a predominance of infection in married individuals [13]. Intra-familial transmission has been proven by Niro et al. in Italy [23]. Tattoos and piercings were also found to be important risk factors for HDV infection, which probably explains the rather high prevalence of infection among young people. Similar results were reported by Gheorghe et al. [14] in Romania. Many studies indicate that sexual transmission is a more important risk factor [24].

\section{Conclusion}

In conclusion, the prevalence of HDV among blood donors in Brazzaville is high and represents a major public health problem with an enormous burden in terms of health expenditure. It is necessary to continue studies on a large sample size.

\section{Funding}

This work was supported and financed by The National Center of Blood Transfusion Congo (CNTS).

\section{Availability of Data and Materials}

The datasets used and/or analysed in this study are available from the corresponding author upon reasonable request.

\section{Conflicts of Interest}

The authors declare no conflict of interest regarding the publication of this paper.

\section{References}

[1] Hepatitis D. http://www.who.int/csr/disease/hepatitis/whocdscsrncs20011/en/index5.html

[2] Rizzetto, M., Hoyer, B. and Canese, M.G. (1980) Delta Agent: Association of Delta Antigen with Hepatitis B Surface Antigen and RNA in Serum of Delta-Infected Chimpanzees. Proceedings of the National Academy of Sciences of the United States of America, 77, 6124-6128. https://doi.org/10.1073/pnas.77.10.6124

[3] Rizzetto, M. (2009) Hepatitis D: Thirty Years After. Journal of Hepatology, 50, 1043-1050. https://doi.org/10.1016/j.jhep.2009.01.004

[4] Gupta, P., Biswas, D., Shukla, I. and Bal, A. (2005) Need for Routine Screening of HBV and HDV in Patients with Cirrhosis of the Liver. Indian Journal of Medical Microbiology, 23, 141-142. https://doi.org/10.1016/S0255-0857(21)02659-1

[5] Sheldon, J., Ramos, B., Toro, C., Rios, P., Martinez, J. and Alarcon Bottecchia, M. (2008) Does Treatment of Hepatitis B Virus (HBV) Infection Reduce Hepatitis Delta Virus HDV Replication in HIV-HBV-HDV Coinfection Patients? Antiviral Therapy, 13, 97-102.

[6] Carmo-Fonseca, J.C. (2002) Hepatitis D. Revista da Sociedade Brasileira de Medicina Tropical, 35, 191. https://doi.org/10.1590/S0037-86822002000200009 
[7] Rizzetto, M., Hoyer, B., Canese, M.G., Pureell, R.H. and Gerin, J.L. (1980) Delta Agent Association of Delta Antigen with Hepatitis B Surface Antigen and RNA in Serum of Delta Infected Chimpanzees. Proceedings of the National Academy of Sciences of the United States of America, 77, 6124-6128. https://doi.org/10.1073/pnas.77.10.6124

[8] Liaw, Y.F., Chiu, K.W., Chu, C.M., Sheen, I.S. and Huang, M.J. (1990) Heterosexual Transmission of Hepatitis Delta Virus in the General Population of an Area Endemic for Hepatitis B Virus Infection: A Prospective Study. The Journal of Infectious Diseases, 162, 1170-1172. https://doi.org/10.1093/infdis/162.5.1170

[9] Chen, H.Y., Shen, D.-T., Ji, D.Z. and Han, P.C. (2019) Prevalence and Burden of Hepatitis D Virus Infection in the Global Population: A Systematic Review and Meta-Analysis. Gut, 68, 512-521. https://doi.org/10.1136/gutjnl-2018-316601

[10] Mumtaz, K., Hamid, S.S., Adil, S., Afaq, A., Islam, M. and Abid, S. (2005) Epidemiology and Clinical Pattern of Hepatitis Delta Virus Infection in Pakistan. Journal of Gastroenterology and Hepatology, 20, 1503-1507. https://doi.org/10.1111/j.1440-1746.2005.03857.x

[11] Andernach, I.E., Leiss, L.V., Tarnagda, Z.S., Tahita, M.C., Otegbayo, J.A., Forbi, J.C., Muller, C.P., et al. (2014) Characterization of Hepatitis Delta Virus in Sub-Saharan Africa. Journal of Clinical Microbiology, 52, 1629-1636.

https://doi.org/10.1128/JCM.02297-13

[12] Mongo-Onkouo, A., Okombi, I.R., Boumba, A., Niama, F.R., Ahoui-Apendi, C.E., Mimiesse Monamou, J.F., Itoua-Ngaporo, N.A., Atipo-Ibara Ollandzobo Ikobo, L.C., Gassaye, D., Ngalessami Mouakosso, M., Adoua, C.S., Atipo-Ibara, B.I. and Ibara, J.R. (2018) Seroprevalence and Molecular Biodiversity of Hepatitis B and Delta Virus Infections in the Republic of Congo. Open Journal of Gastroenterology, 8, 448-454. https://doi.org/10.4236/ojgas.2018.812046

[13] Mansour, W., Bollahi, M.A., Hamed, C.T., Brichler, S., Le Gald, F., Ducancelle, A., Lô, B., Gordien, E., Rosenheim and Lunel, F. (2012) Virological and Epidemiological Features of Hepatitis Delta Infection among Blood Donors in Nouakchott, Mauritania. Journal of Clinical Virology, 55, 12-16.

https://doi.org/10.1016/j.jcv.2012.05.011

[14] Gheorghe, L., Csiki, I.E., Iacob, S., Gheorghe, C., Trifan, A., Grigorescu, M., Motoc, A. and Alexandrescu, A. (2015) Hepatitis Delta Virus Infection in Romania: Prevalence and Risk Factors. Journal of Gastrointestinal and Liver Diseases, 24, 413-421. https://doi.org/10.15403/jgld.2014.1121.244.dtv

[15] Delfino, C.M., Gentile, E.A., Castillo, A.I., Cuestas, M.L., Pataccini, G., Camila Canepa, C., Malan, R., Blejer, J., Berini, C., Eirin, M.E., Pedrozo, W., Biglione, M.M. and Mathet, V.L. (2013) Hepatitis B Virus and Hepatitis D Virus in Blood Donors from Argentina: Circulation of HBsAg and Reverse Transcriptase Mutants. Archives of Virology, 22, 213-216.

[16] Uzun, B., Sener, A.G., Güngör, S., Afsar, I. and Demirci, M. (2014) Evaluation of Hepatitis Delta Virus (HDV) Infection in Blood Donors in Western Turkey. Transfusion and Apheresis Science, 45, 145-151.

[17] Sawadogo, A., Ouédraogo, A.S., et al. (2016) Séroprévalence de l'infection par le virus de l'hépatite $\mathrm{D}$ dans une population de donneurs de sang porteurs de l'Antigène HBs au Centre régional de transfusion sanguine de Bobo-Dioulasso. Journal Africain d Hépato-Gastroentérologie, 10, 31-33.

https://doi.org/10.1007/s12157-015-0646-4

[18] Luma, H.N., Eloumou, S., Okalla, C., Donfack-Sontsa, O., Koumitana, R., Malon- 
gue, A., Ayiss, G.B. and Noah, D.N. (2017) Prevalence and Characteristics of Hepatitis Delta Virus Infection in a Tertiary Hospital Setting in Cameroon. Journal of Clinical and Experimental Hepatology, 7, 334-339.

https://doi.org/10.1016/j.jceh.2017.05.010

[19] Gomaa, N., Metwally, L.A., Nemr, M. and Younis, S. (2013) Seroprevalence of HDV Infection in HBsAg Positive Population in Ismailia, Egypt. The Egyptian Journal of Immunology, 20, 23-28.

[20] Angounda, B.M., Bokilo, A., Niama, F.R., et al. (2016) Seroprevalence of Markers and Risk Factors of Hepatitis B Virus among Blood Donors in Brazzaville, Congo. International Journal of Innovation and Scientific Research, 20, 171-179.

[21] Kakisingi, C.M., Matanda, S.K. and Manika, M. (2016) Profil épidémiologique et séroprévalence des donneurs de sang aux cliniques universitaires de Lubumbashi République Démocratique du Congo. Pan African Medical Journal, 23, 1-9. https://doi.org/10.11604/pamj.2016.23.175.8480

[22] Alizadeh, A.H., Ranjbar, M., Tehrani, A.S., Keramat, F., Mamanic, M., Rezazadeh, M., Aini, P., Khalilian, A. and Hajilooi, M. (2010) Seroprevalence of Hepatitis D Virus and Its Risk Factors in the West of Iran. Journal of Microbiology, Immunology and Infection, 43, 519-523. https://doi.org/10.1016/S1684-1182(10)60080-1

[23] Niro, G.A., Casey, J.L., Gravinese, E., et al. (1999) Intrafamilial Transmission of Hepatitis Delta Virus: Molecular Evidence. Journal of Hepatology, 30, 564-569. https://doi.org/10.1016/S0168-8278(99)80185-8

[24] Noureddin, M. and Gish, R. (2014) Hepatitis Delta: Epidemiology, Diagnosis and Management: 36 Years after Discovery. Current Gastroenterology Reports, 16, 364-383. https://doi.org/10.1007/s11894-013-0365-x 